\title{
Antioxidant, anticholinesterase activities and polyphenolic constituents of cones of algerian fir (Abies numidica) by LC- ESI-MS/MS with chemometric approach
}

\author{
Habiba MOKADDEM-DAROUI 1, 2 (D), Maya BELHADJ MOSTEFA ${ }^{1}$ iD, Fatma AYDOGMUS-OZTURK ${ }^{4}$ iD, \\ Ebru EROL ${ }^{3}$ (D), Mehmet OZTURK ${ }^{3 *}$ (D), Abdulselam ERTAŞ ${ }^{5}$ (D), Mehmet EMIN DURU ${ }^{3}$ (D), \\ Ahmed KABOUCHE ${ }^{1}$ (D), Zahia KABOUCHE ${ }^{1}$ * (D) \\ 1 Université des Frères Mentouri-Constantine 1, Laboratoire d'Obtention de Substances Thérapeutiques (LOST), 25000 \\ Constantine, Algeria. \\ 2 University Badji-Mokhtar Annaba, Faculty of Medicine, 23000 Annaba, Algeria. \\ 3 Department of Chemistry, Faculty of Sciences, Mugla Sıtkı Koçman University, 48121 Muğla, Turkey. \\ 4 Köyceğiz Vocational School, Mugla Sttkı Koçman University, 48121 Muğla, Turkey. \\ 5 Department of Pharmacognosy, Faculty of Pharmacy, Dicle University, 21280 Diyarbakir, Turkey. \\ * Corresponding Author. E-mail: mehmetozturk@mu.edu.tr (M.O.) and kabouchezahia@gmail.com (Z.K.); Tel. +90- \\ 252-2113138.
}

Received: 12 November 2020 / Revised: 01 January 2021 / Accepted: 23 February 2021

ABSTRACT: The fractions (Fr.1-5) of the hydromethanolic extract of Abies numidica cones were studied for their polyphenol constituents, antioxidant, and anticholinesterase activities. The $\beta$-carotene-linoleic acid, cupric reducing power (CUPRAC), DPPH scavenging, and ABTS radical scavenging assays were used to determine antioxidant activity. Fr.3 exhibited the highest antioxidant activity in ABTS test ( $\mathrm{IC}_{50}: 1.29 \mu \mathrm{g} / \mathrm{mL}$ ), b-carotene-linoleic acid test (IC $\mathrm{I}_{50}: 18.6$ $\mu \mathrm{g} / \mathrm{mL})$ and CUPRAC $\left(\mathrm{A}_{0.5}: 33.8 \mu \mathrm{g} / \mathrm{mL}\right)$ assays. Three fractions (Fr.2-4) promising antioxidant activity were analyzed using LC-MS/MS for their phenolic compositions. Taxifolin (155.9-2816.2 $\mu \mathrm{g}$ analyte/g extract), hyperoside (353.0$2045.5 \mu \mathrm{g} / \mathrm{g})$, vanillin $(1488.9-1529.9 \mu \mathrm{g} / \mathrm{g})$, tannic acid (1281.6-1416.8 $\mu \mathrm{g} / \mathrm{g})$, rosmarinic acid $(1063.1-1149.3 \mu \mathrm{g} / \mathrm{g})$, coumarin $(683.0-772.6 \mu \mathrm{g} / \mathrm{g})$, quercetin $(881.0 \mu \mathrm{g} / \mathrm{g})$, and catechin $(277.7-400.2 \mu \mathrm{g} / \mathrm{g})$ were identified in the antioxidant fractions. Moreover, the anticholinesterase activity was also performed using the in vitro spectroscopic Ellman method. The antioxidant fractions exhibited moderate butyrylcholinesterase inhibitory activity. The multi-ware analysis was performed to understand the origin of bioactivities. According to principal component analysis, it is detected that the hyperoside, catechin, taxifolin, and tannic acid were responsible for the antioxidant activity. Therefore, the cones of Abies numidica can be considered as potent antioxidant and anticholinesterase sources in food and pharmaceutical industries, commercially.

KEYWORDS: Abies numidica; LC-MS/MS; antioxidant activity; anticholinesterase activity; taxifolin; hyperoside.

\section{INTRODUCTION}

Fir is the name given to the coniferous tree species of Abies genus of Pinaceae family. Firs that can grow up to $40 \mathrm{~m}$ can be distinguished from other types of Pinaceae family with their unique form, trunk bark needle leaves and even their scent. Firs have white lines on the lower surface of the leaves. In the autumn months, the flakes of the cones fall off when they mature. Fir species generally develop well in semi-shade environments. They prefer moist and fertile forest soils. They also grow well on moist, sandy or clay soils. They do not like calcareous soils.

The genus Abies "fir" (Pinaceae) consists of 51 species mainly distributed in temperate and boreal regions of the Northern hemisphere, particularly in mountainous regions such as North Africa, Himalayas and Turkey $[1,2]$.

Abies species are used as antibacterial, anti-rheumatism, diuretic, expectorant, vasoconstrictor, and wound healing agents [3]. Previously, lignans, flavonoids [4], stilbenes, chalcones [5], sesquiterpenoids [6], triterpenoids and tetraterpenoids [7] exhibiting various biological activities [8,9] has been isolated from the Abies genus. So far, there are a few chemicals and biological activity studies on Abies numidica. In a very recent

How to cite this article: Mokaddem-Daroui H, Belhadj Mostefa M, Ozturk M, Erol E, Aydogmus-Ozturk F, Ertaş A, Duru ME, Kabouche A, Kabouche Z. Antioxidant, anticholinesterase activities and polyphenolic constituents of cones of algerian fir (Abies numidica) by LC-ESI-MS/MS with chemometric approach. J Res Pharm. 2021; 25(3): 230-237. 
study, the needles of Abies numidica was studied [10]. In another study, eight diterpenes were isolated from the cones of A. numidica [11]. In continuation of works on antioxidant anticolinesterase potential of Algerian plants [11-17], the present study aimed to investigate the phenolic compounds of cones of Abies numidica using LC-ESI-MS/MS and their antioxidant and anticholinesterase activities, for the first time.

\section{RESULTS AND DISCUSSION}

\subsection{Antioxidant activity}

In ABTS and DPPH assays, Fr.3 exhibited the highest activity ( $\mathrm{IC}_{50}: 1.29 \pm 0.02 \mu \mathrm{g} / \mathrm{mL}$ and $120.7 \pm 0.8$ $\mu \mathrm{g} / \mathrm{mL}$ respectively), followed by Fr.2 (IC $50: 12.8 \pm 0.1 \mu \mathrm{g} / \mathrm{mL}$ and $160.6 \pm 0.6 \mu \mathrm{g} / \mathrm{mL}$ ) and Fr.4 (IC $50: 77.8 \pm 0.2$ $\mu \mathrm{g} / \mathrm{mL}$ and $162.3 \pm 1.2 \mu \mathrm{g} / \mathrm{mL}$ ). Fr.3 also exhibited better activity than that of a-tocopherol (IC ${ }_{50}: 4.33 \pm 0.1$ $\mu \mathrm{g} / \mathrm{mL})$ and BHT $\left(\mathrm{IC}_{50}: 4.11 \pm 0.1 \mu \mathrm{g} / \mathrm{mL}\right)$ in ABTS assay but a lower DPPH radical scavenging activity than those of standards (Table 1). In fact, in DPPH assay, due to the steric hindrance, some of the compounds having bulky groups are unable to approach the free radical to scavenge it, appropriately. In contrast, ABTS assay can test these types of antioxidants having bulky groups. The DPPH assay supported the ABTS and total phenolic concentration assays. In $\beta$-carotene-linoleic acid assay, Fr.3 ( $\mathrm{IC}_{50}: 18.6 \pm 1.1 \mu \mathrm{g} / \mathrm{mL}$ ) also demonstrated the best activity and followed by Fr.2 (IC $50: 113.8 \pm 2.1 \mu \mathrm{g} / \mathrm{mL}$ ) and Fr.4 (IC $50: 125.6 \pm 1.2 \mu \mathrm{g} / \mathrm{mL}$ ). All tested fractions exhibited a lower activity than those of BHT and a-tocopherol. The lipid peroxidation inhibitory results are in accordance with those of ABTS and DPPH assays, which confirms once again, the relationship between polyphenols and antioxidant activity (Table 1 ).

In the CUPRAC assay, Fr.2 and Fr.3 exhibited a very close activity to each other $\left(\mathrm{A}_{0.5}: 31.2 \pm 0.1 \mu \mathrm{g} / \mathrm{mL}\right.$; $\mathrm{A}_{0.5}: 33.8 \pm 0.2 \mu \mathrm{g} / \mathrm{mL}$, respectively). However, Fr.4 (A $\left.\mathrm{A}_{0.5}: 183.0 \pm 0.4 \mu \mathrm{g} / \mathrm{mL}\right)$ exhibited the lowest cupric, reducing antioxidant capacity (Table 1 ).

Table 1. Total phenolic content and antioxidant and anticholinesterase activities of fractions (Fr.2-4) of Abies numidica cones by four complementary assays.

\begin{tabular}{|c|c|c|c|c|c|c|c|}
\hline \multirow[b]{2}{*}{ Fractions } & \multirow{2}{*}{$\begin{array}{l}\text { Phenolic } \\
\text { contents }\end{array}$} & \multicolumn{4}{|c|}{$\begin{array}{l}\text { Antioxidant } \\
\text { activity }\end{array}$} & \multicolumn{2}{|c|}{$\begin{array}{c}\text { Anticholinesterase } \\
\text { activity }\end{array}$} \\
\hline & & $\begin{array}{l}\text { DPPH } \\
\text { assay }\end{array}$ & $\begin{array}{l}\text { ABTS } \\
\text { assay }\end{array}$ & $\begin{array}{c}\beta \text {-Carotene- } \\
\text { linoleic } \\
\text { acid assay }\end{array}$ & $\begin{array}{c}\text { CUPRAC } \\
\text { assay }\end{array}$ & $\begin{array}{l}\text { AChE } \\
\text { assay }\end{array}$ & $\begin{array}{l}\text { BChE } \\
\text { assay }\end{array}$ \\
\hline & $\begin{array}{l}\text { ( } \mu \text { g GAEs } / \mathrm{mg} \\
\text { extract) }{ }^{a}\end{array}$ & $\begin{array}{c}\mathrm{IC}_{50} \\
(\mu \mathrm{g} / \mathrm{mL})^{b}\end{array}$ & $\begin{array}{c}\mathrm{IC}_{50} \\
(\mu \mathrm{g} / \mathrm{mL})^{b}\end{array}$ & $\begin{array}{c}\mathrm{IC}_{50} \\
(\mu \mathrm{g} / \mathrm{mL})^{b}\end{array}$ & $\begin{array}{c}\mathbf{A}_{0.5} \\
(\mu \mathrm{g} / \mathrm{mL})^{b, c}\end{array}$ & $\begin{array}{c}\mathrm{IC}_{50} \\
(\mu \mathrm{g} / \mathrm{mL})^{b}\end{array}$ & $\begin{array}{c}\mathrm{IC}_{50} \\
(\mu \mathrm{g} / \mathrm{mL})^{b}\end{array}$ \\
\hline Fr.2 & $138.2 \pm 0.8$ & $160.6 \pm 0.6$ & $12.8 \pm 0.1$ & $113.8 \pm 2.1$ & $31.2 \pm 0.1$ & $>200$ & $187.8 \pm 2.1$ \\
\hline Fr.3 & $157.6 \pm 0.2$ & $120.7 \pm 0.8$ & $1.29 \pm 0.02$ & $18.6 \pm 1.1$ & $33.8 \pm 0.2$ & $>200$ & $176.6 \pm 1.3$ \\
\hline Fr.4 & $47.4 \pm 0.0$ & $162.3 \pm 1.2$ & $77.8 \pm 0.2$ & $125.6 \pm 1.2$ & $183.0 \pm 0.4$ & $>200$ & $83.8 \pm 0.8$ \\
\hline a-Tocopherol & $N T$ & $7.3 \pm 0.2$ & $4.3 \pm 0.1$ & $2.1 \pm 0.1$ & $2.6 \pm 0.01$ & $N T$ & NT \\
\hline $\mathrm{BHT}^{d}$ & NT & $45.4 \pm 0.5$ & $4.1 \pm 0.1$ & $1.3 \pm 0.04$ & $3.8 \pm 0.01$ & NT & NT \\
\hline Galantamine & NT & NT & NT & $N T$ & NT & $5.01 \pm 0.1$ & $53.9 \pm 0.6$ \\
\hline
\end{tabular}

aGAEs, gallic acid equivalents, and the values represents the mean \pm S.E.M. of three parallel measurements ( $p<0.05)$.

${ }^{b} C_{50}$ values and ${ }^{c} A_{0.5}$ values represent the means \pm S.E.M. of three parallel measurements $(p<0.05)$.

${ }^{c} \mathrm{~A}_{0.5}$ symbol correspond the $\mu \mathrm{g} / \mathrm{mL}$ concentration of 0.500 Absorbance value.

dBHT: Butylated hydroxy toluene; NT: not tested.

\subsection{Total phenolic concentration results}

The phenolic compounds concentrations of each fraction were tested, and the results were expressed as $\mu \mathrm{g}$ of gallic acid per $\mathrm{mg}$ of the fraction (Table 1). Fr.3 $(157.6 \pm 0.2 \mathrm{mg} / \mathrm{g})$ had a higher phenolic content than the others. These results were parallel to the phenolic concentration of Pinus densiflora [18].

\subsection{Anticholinesterase activities}

The fractions indicating antioxidant activity were tested for their acetyl- and butyrylcholinesterase inhibitory activities. Galantamine was used as a positive standard to compare the activity. Among the extracts, there was no unusual activity against the acetylcholinesterase enzyme. However, moderate activity was detected against butyrylcholinesterase enzyme (Table 1). Fr.4 having the lowest phenolic content and indicating the lowest antioxidant activity exhibited the best butyrylcholinesterase inhibitory activity with an 
$\mathrm{IC}_{50}$ value of $83.8 \pm 0.8 \mu \mathrm{g} / \mathrm{mL}$ among the other fractions. The anticholinesterase activity and antioxidant activity results were different in that they were unable to support each other, as given in the literature [19]. Fr.3, the best antioxidant fraction indicated moderate butyrylcholinesterase inhibitory activity $\left(\mathrm{IC}_{50}\right.$ : $176.6 \pm$ $1.3 \mu \mathrm{g} / \mathrm{mL}$ ). Since the fractions are a mixture of many compounds, synergistic or anti-synergistic effects may play a vital role in exhibiting the anticholinesterase activity.

\subsection{Quantitative analysis of phenolic compounds by LC-MS/MS}

The selected fractions were analyzed using LC-ESI-MS/MS with the use of the positive and negative ionization modes. The negative ion mode showed better sensitivity than that of positive. The LC-MS/MS results were parallel to that the total phenolic content analyses (Table 2). Fr.2 and Fr.3 had rich phenolic content because of their high amounts of taxifolin, vanillin, and rosmarinic acid. Fr.3 exhibited the highest antioxidant activity; this can be explained by the high content of taxifolin and hyperoside $(2816.2 \pm 6.3$, and $2045.5 \pm 3.1 \mu \mathrm{g}$ analyte/g extract, respectively). Besides the high concentrations of those compounds, Fr.3 also contained significant amounts of vanillin (1488.9 $\pm 3.5 \mu \mathrm{g}$ analyte/g extract), tannic acid $(1416.8 \pm 3.7 \mu \mathrm{g} / \mathrm{g})$, rosmarinic acid $(1136.6 \pm 3.0 \mu \mathrm{g} / \mathrm{g})$, quercetin $(881.0 \pm 05 \mu \mathrm{g} / \mathrm{g})$, coumarin $(772.6 \pm 0.6 \mu \mathrm{g} / \mathrm{g})$ and catechin $(400.2 \pm 0.7$ $\mu \mathrm{g} / \mathrm{g})$.

Table 2. Constituents of the fractions of aqueous methanol extract of Abies numidica a.

\begin{tabular}{clcccc}
\hline \multirow{2}{*}{ No } & \multicolumn{1}{c}{ Analyte } & RT $\mathbf{b}$ & \multicolumn{3}{c}{ Quantification $(\boldsymbol{\mu g}$ analyte/g extract) $\mathbf{c}$} \\
& & & Fr.2 & Fr.3 & Fr.4 \\
\hline $\mathbf{1}$ & Quinic acid & 3.32 & $2149.4 \pm 8.4$ & $8297.4 \pm 20.7$ & - \\
$\mathbf{2}$ & Malic acid & 3.54 & $7704.6 \pm 23.5$ & $7663.0 \pm 16.5$ & - \\
$\mathbf{3}$ & Gallic acid & 4.29 & $D$. & $D$. & $D$. \\
$\mathbf{4}$ & Chlorogenic acid & 5.43 & - & $D$. & - \\
$\mathbf{5}$ & Protocatechuic acid & 5.63 & $D$. & $D$. & - \\
$\mathbf{6}$ & Tannic acid & 6.46 & $1281.6 \pm 4.3$ & $1416.8 \pm 3.7$ & $35.0 \pm 1.2$ \\
$\mathbf{7}$ & tr-Caffeic acid & 7.37 & $D$. & $D$. & - \\
$\mathbf{8}$ & Vanillin & 8.77 & $1529.9 \pm 5.5$ & $1488.9 \pm 3.5$ & $1511.9 \pm 3.5$ \\
$\mathbf{9}$ & Taxifolin & 9.00 & $1311.3 \pm 1.7$ & $2816.2 \pm 6.3$ & $155.91 \pm 0.4$ \\
$\mathbf{1 0}$ & Catechin & 9.33 & $200.23 \pm 0.7$ & $400.23 \pm 0.7$ & $77.77 \pm 0.4$ \\
$\mathbf{1 1}$ & p-Coumaric acid & 9.53 & $D$. & $D$. & - \\
$\mathbf{1 2}$ & Rosmarinic acid & 9.57 & $1149.3 \pm 3.5$ & $1136.6 \pm 3.0$ & $1063.1 \pm 2.5$ \\
$\mathbf{1 3}$ & Rutin & 9.69 & - & $D$. & - \\
$\mathbf{1 4}$ & Hesperidin & 10.18 & $D$. & $D$. & - \\
$\mathbf{1 5}$ & Hyperoside & 10.43 & $353.0 \pm 1.6$ & $2045.5 \pm 3.1$ & $42.0 \pm 1.5$ \\
$\mathbf{1 6}$ & Coumarin & 12.52 & $683.0 \pm 0.5$ & $772.6 \pm 0.6$ & $727.9 \pm 0.5$ \\
$\mathbf{1 7}$ & Quercetin & 14.48 & - & $881.0 \pm 0.5$ & - \\
$\mathbf{1 8}$ & Hesperetin & 15.29 & $D$. & $D$. & - \\
\hline
\end{tabular}

${ }^{a}$ The values represents the mean \pm S.E.M. of three parallel measurements $(p<0.05)$.

b RT: Retention time.

c Values in $\mu \mathrm{g} / \mathrm{g}(\mathrm{w} / \mathrm{w})$ of fraction

$D$ : peak observed, concentration is lower than the LOQ but higher than the LOD

Dash means no activity

The identified phenolic and/or flavonoid compounds are known that they have powerful antioxidant capacity. The highest antioxidant activity can be explained due to the presence of antioxidant compounds in the Fr.3. Fraction 2 also indicated a slightly lower activity than Fr.3. Higher activity of them may be due to taxifolin and hyperoside concentration. In addition, quercetin, which is also a powerful antioxidant, was absent in Fr.2. In addition to the high concentrations of vanillin and taxifolin $(1529.9 \pm 5.5$, and $1311.3 \pm 1.7 \mu \mathrm{g}$ analyte/g extract, respectively), Fr.2 also contained significant amount of tannic acid (1281.6 $\pm 4.3 \mu \mathrm{g}$ analyte/g extract, respectively), rosmarinic acid $(1149.3 \pm 3.5 \mu \mathrm{g} / \mathrm{g})$, coumarin $(683.0 \pm 0.5 \mu \mathrm{g} / \mathrm{g})$, hyperoside $(353.0 \pm 1.6$ $\mu \mathrm{g} / \mathrm{g})$ and catechin $(200.2 \pm 0.7 \mu \mathrm{g} / \mathrm{g})$ (Table 2). The Fraction 4 presenting the lowest antioxidant activity contained vanillin $(1511.9 \pm 3.5 \mu \mathrm{g} / \mathrm{g})$, rosmarinic acid $(1063.1 \pm 2.5 \mu \mathrm{g} / \mathrm{g})$, coumarin $(727.9 \pm 0.5 \mu \mathrm{g} / \mathrm{g})$ and taxifolin $(155.9 \pm 1.0 \mu \mathrm{g} / \mathrm{g})$ and catechin $(77.8 \pm 0.4 \mu \mathrm{g} / \mathrm{g})$. Moreover, Fr.2 and Fr.3 also contained high amounts of quinic acid $(2149.4 \pm 8.4 \mu \mathrm{g} / \mathrm{g}$ and $8297.4 \pm 20.7 \mu \mathrm{g} / \mathrm{g}$, respectively) and malic acid $(7704.6 \pm 23.5 \mu \mathrm{g} / \mathrm{g}$ and 
$7663.0 \pm 16.5 \mu \mathrm{g} / \mathrm{g}$, respectively) (Table 2). The latter information is even necessary for the targeted isolation of taxifolin and hyperoside.

This is the first study on Abies numidica cones, which reported such a high amount of phenolic compounds such as taxifolin, hyperoside, and vanillin. It could be said that Abies numidica is a new source of antioxidant polyphenols.

\subsection{Principal component analysis (PCA) of Abies numidica fractions}

The results of 9 common organic/phenolic compounds and five complementary bioactivities of Abies numidica were analyzed using Principal Component Analyses (PCA). Two principal components explained all data. The eigenvalue of PC1 11.295 while of PC2 was 3.705. The remaining were zero. Briefly, the first component (PC1) explained $75.3 \%$, while PC2 $27.4 \%$ of the variance (Table 3), and the first two principal components explained $100.0 \%$ of the total variance. The main components defining the dominant values were highlighted bold in Table 3. The highest variance belonged to PC1 in the dataset. Taxifolin, catechin, quinic acid, tannic acid, hyperoside, malic acid, and rosmarinic acid were dominant in PC1, while coumarin and hyperoside were in PC2. Table 4 shows the score values of the two principal components. Herein, it was observed that Fr.3 could be characterized with taxifolin, catechin, quinic acid, tannic acid, hyperoside, malic acid and rosmarinic for the PC1, and also characterized with coumarin and hyperoside for PC2.

Table 3. The loadings, eigenvalues variance and cumulative variance values for principal components of Fractions of Abies numidica.

\begin{tabular}{|c|c|c|}
\hline Organic/phenolic compounds & Principal Component 1 & Principal Component 2 \\
\hline Quinic acid & 0.282056 & 0.165809 \\
\hline Malic acid & 0.264490 & -0.238058 \\
\hline Tannic acid & 0.276091 & -0.193939 \\
\hline Vanillin & -0.153592 & -0.444511 \\
\hline Taxifolin & 0.295246 & 0.065945 \\
\hline Catechin & 0.292322 & 0.097835 \\
\hline Rosmarinic acid & 0.244187 & -0.296752 \\
\hline Hyperoside & 0.270489 & 0.216606 \\
\hline Coumarin & 0.134963 & 0.462524 \\
\hline Total phenolic content & 0.283810 & -0.156446 \\
\hline DPPH assay & -0.255427 & -0.266446 \\
\hline ABTS assay & -0.281412 & 0.169101 \\
\hline$\beta$-Carotene-linoleic assay & -0.264691 & -0.237378 \\
\hline CUPRAC assay & -0.263076 & 0.242776 \\
\hline BChE Inhibitory assay & 0.250578 & -0.280092 \\
\hline Eigenvalue & 11.287 & 3.713 \\
\hline Variance $(\%)$ & 75.2 & 24.8 \\
\hline Cumulative (\%) & 75.2 & 100 \\
\hline
\end{tabular}

Accordingly, Fr.4 was negatively characterized by taxifolin, catechin, quinic acid, tannic acid, hyperoside, malic acid, and rosmarinic for PC1, which means that the amounts of said compounds were slightly less in Fr.4. In the biplot graph, Figure 1 indicates that Fr. 4 was looked like negatively characterized by $\mathrm{BChE}$ inhibitory assay. Since the $\mathrm{IC}_{50}$ value used to express the activity, the direction of the $\mathrm{BChE}$ assay should be thought the reverse because the decreasing $\mathrm{IC}_{50}$ value indicates increasing activity. Thus, it revealed that Fr. 4 was rich in BChE inhibitory compounds. As in BChE inhibitory assay, all bioactivities were expressed with $\mathrm{IC}_{50}$ values except total phenolic content. Similarly, considering Figure 1, Fr.3, also characterized by $\mathrm{DPPH}, \mathrm{ABTS}$, CUPRAC, and $\beta$-carotene-linoleic assays, was rich in antioxidant compounds.

Table 4. The scores of the two rotated principal components.

\begin{tabular}{ccc}
\hline Samples & Principal Component 1 & Principal Component 2 \\
\hline Fr.2 & 0.20053 & -2.22217 \\
Fr. 3 & 3.25479 & $\mathbf{1 . 2 1 0 7 0}$ \\
Fr. 4 & -3.45532 & 1.01147 \\
\hline
\end{tabular}

According to biplot graph, hyperoside, catechin, taxifolin, coumarin, and tannic acid directed to Fr.3 (Right-up corner). Correspondingly, since the reverse direction should be though for CUPRAC, ABTS, DPPH, and $\beta$-carotene-linoleic acid assays, the said bioactivities could direct to Fr.3, as well (Reverse direction was 
right - up corner). Thus, it could be seen that the antioxidant activity assays, and the said compounds were directed in the same direction. Therefore, it can be concluded that hyperoside, catechin, taxifolin, coumarin, and tannic acid could be the main compounds responsible for the antioxidant activity of Fr.3. Similarly, tannic acid, rosmarinic acid, and malic acid could be said that they were in less amount in Fr.4. The lesser antioxidant activity of Fr.4 may be due to the fewer amounts of said antioxidant compounds. Comparatively, the antioxidant activity of Fr.2 was higher than Fr.4. The biplot graph also showed that the Fr.2 location was closer to said antioxidant compounds when compare with Fr.4 (Figure 1).

\section{CONCLUSION}

The phenolic ingredients and antioxidant and anticholinesterase activity of cones of A. numidica were investigated in this study. Among the detected eighteen compounds in the VLC fractions, ten of them were quantified. Taxifolin was the major phenolic compound, while quinic acid and malic acids were the major non-phenolic compounds. The fractions exhibited high antioxidant activity in all test assays. Particularly the antioxidant activity of Fr.3, which was rich in hyperoside, taxifolin, vanillin, tannic acid, and rosmarinic acid, was the superior. Fr. 3 could also be a source of the hyperoside and taxifolin, which were the main compounds responsible for high antioxidant activity as proved using principal component analyses. Fr. 2 was also a good source of vanillin, malic acid, tannic acid and taxifolin. Besides, according to multi ware analyses, Fr.4 could contain butyrylcholinesterase inhibitory compounds. We can conclude that Abies numidica cones are potent antioxidants and moderate butyrylcholinesterase inhibitors. It should be added that further studies, particularly in vivo tests, should be carried out to use the cones of Abies numidica in Food and pharmaceutical industry as preservatives or moderate anticholinesterase agents.

\section{MATERIALS AND METHODS}

\subsection{Plant collection and extraction}

Cones of A. numidica de Lannoy ex Carrière were collected from Constantine (Algerian Eastern), in November 2013 and identified by Professor Gérard De Bélair, University of Badji-Mokhtar- Annaba, Algeria. A voucher specimen (Lost An/11.13) has been deposited in the herbarium of the University Frères Mentouri - Constantine 1.

Air-dried and powdered cones $(100 \mathrm{~g})$ were extracted with $70 \% \mathrm{MeOH}(3 \times 24$ hours) to give $3.2 \mathrm{~g}$ of a crude extract after evaporation of the solvent. The residue was subjected to vacuum liquid chromatography (VLC) on reversed-phase silica gel $\left(\mathrm{C}_{18}, 15-25 \mu \mathrm{m}\right.$, Sigma-Aldrich). The elution started with $20 \%$ methanol in water and continued gradients of $20 \% \mathrm{MeOH}$. The elution stopped after reached $100 \%$ methanol. Five fractions (Fr. 1-5) were collected. After the solvents removed under vacuum, $95.1 \mathrm{mg}, 1005 \mathrm{mg}, 1202 \mathrm{mg}, 850 \mathrm{mg}$, and $47.9 \mathrm{mg}$ crude fractions were obtained. $2.5 \mathrm{mg}$ of the fractions were carefully weighted and solvedin $10 \mathrm{~mL}$ solvent, and then filtrated with $0.22 \mu \mathrm{m}$ PTFE before LC-MS/MS analyses.

\subsection{Chemicals and instruments}

Chemical compositions of cones of A. numidica were determined by using LC-MS/MS (Shimadzu, Kyoto, Japan). Malic acid (95-100\%), protocatechuic acid (97\%), quercetin (95\%), rutin $(94 \%)$, chrysin $(97 \%)$, naringenin (95\%), hesperetin (95\%), rosmarinic acid (96\%),vanillin $(99 \%)$, caffeic acid $(98 \%), p$-coumaric acid $(98 \%)$, chlorogenic acid $(95 \%)$, hyperoside $(\geq 97 \%)$, myricetin $(\geq 96 \%)$, kaempferol $(\geq 97 \%)$, coumarin $(\geq 99 \%)$, formic acid $(\leq 100 \%)$ were obtained from Sigma (Germany), quinic acid $(98 \%)$, hydroxybenzoic acid ( $\geq 99 \%)$, tr-aconitic acid (98\%),4- $\alpha$-tocopherol ( $\geq 95.5 \%)$, fisetin ( $\geq 98 \%)$ were from Aldrich (Germany); gallic acid $(\geq 99 \%)$, salicylic acid $(\geq 99 \%)$, tannic acid (puris) were from Sigma-Aldrich (Germany); hesperidin ( $\geq 97 \%)$, apigenin $(\geq 99 \%)$, luteolin $(\geq 97 \%)$, rhamnetin $(\geq 99 \%)$ were from R-Biopharm, as certified reference materials.

Antioxidant and anticholinesterase activities measurements were carried out on a 96-well microplate reader, SpectraMax 340PC384, Molecular Devices (USA). Ammonium acetate, copper (II) chloride and potassium persulfate were obtained from E. Merck (Darmstadt, Germany). Follin-ciocalteu reagent, sodium carbonate, gallic acid, a-tocopherol, 1,1-diphenyl-2-picrylhydrazyl (DPPH), butylated hydroxytoluene (BHT), 2,2'-Azinobis (3-ethyl-benzothiazoline-6-sulphonic acid) diammonium salt (ABTS), Electrophorus electricus (electric eel) acetylcholinesterase (Type-VI-S, EC 3.1.1.7, $425.84 \mathrm{U} / \mathrm{mg}$, Sigma), horse serum butyrylcholinesterase (EC 3.1.1.8, 11.4 U/mg, Sigma), 5,5'-dithiobis (2-nitrobenzoic) acid (DTNB), galantamine, acetylthiocholine iodide, and butyrylthiocholine iodide were obtained from Sigma Chemical Co. (Sigma-Aldrich GmbH, Sternheim, Germany). 


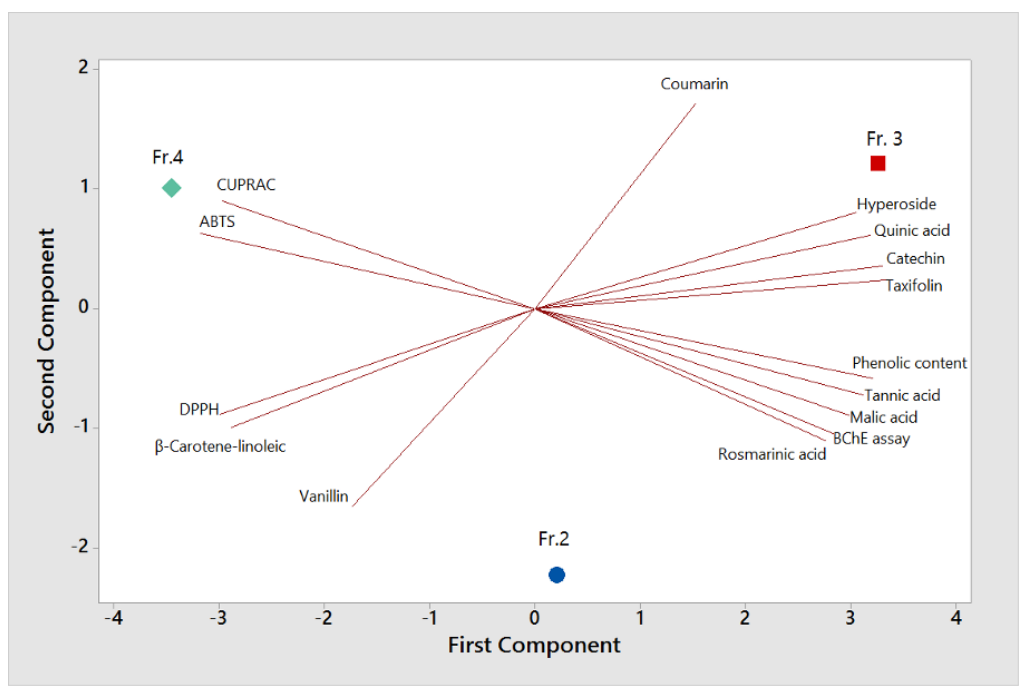

Figure 1. Biplot graph for PC1 (1st Principal Component) and PC2 (2nd Principal Component) in Abies numidica fractions, $\bullet$ Fr. 2, $\bullet$ Fr. 3, $\gg$ Fr. 4.

\subsection{Quantitative analysis of phenolic compounds using LC-MS/MS}

Nexera model Shimadzu LC coupled to a tandem MS instrument and equipped with LC-30AD binary pumps, DGU-20A3R degasser, CTO-10ASvp column oven, and SIL-30AC autosampler were used in LCMS/MS analyses of phenolic compounds of fractions. The separation was performed on a $\mathrm{C}_{18}$ reversed-phase inertsil ODS-4 $(150 \mathrm{~mm} \times 4.6 \mathrm{~mm}, 3 \mu \mathrm{m})$ analytical column. The flow rate was $0.5 \mathrm{~mL} / \mathrm{min}$, injection volume was $4 \mu \mathrm{L}$, and the column temperature was $40{ }^{\circ} \mathrm{C}$. Mobile phase $\mathrm{A}(0.1 \%$ formic acid in ultrapure water $)$ and mobile phase $B(0.1 \%$ formic acid in methanol) were used for the elution. The gradient program with the following proportions of solvent B was applied t (min), \%B: $(0,40),(20,90),(23.99,90),(24,40),(29,40)$.

MS detection was performed using a Shimadzu LCMS 8040 model triple quadrupole mass spectrometer equipped with an ESI source operating in both positive and negative ionization modes. MRM (The multiple reaction monitoring) modes were used to quantify the analyses: the assay of investigated compounds was performed following two or three transitions per compound, the first one for quantitative purposes, and the second and/or the third one for confirmation. LC-MS/MS data were collected and processed by LabSolutions software (Shimadzu, Kyoto, Japan).

\subsection{Optimization and method validation parameters for LC-MS/MS}

Since the phenolic and organic acids were relatively polar compounds, ESI source was preferred. The ESI conditions were adjusted as following: interface temperature to $350{ }^{\circ} \mathrm{C}$, DL temperature to $250{ }^{\circ} \mathrm{C}$, block heat temperature to $400{ }^{\circ} \mathrm{C}$, nebulizing gas, nitrogen, flow to $3 \mathrm{~L} / \mathrm{min}$, and drying gas, nitrogen, and flow to $15 \mathrm{~L} / \mathrm{min}$.

Twenty-seven compounds that are widespread in plants, including flavonoids, flavonoid glycosides, phenolic acids, phenolic aldehyde, coumarin, non-phenolic organic acids were chosen for validation parameters. The limit of detection (LOD) and limit of quantitation (LOQ) of the method were same previously published paper [20]. Briefly, for the studied compounds, LOD ranged between 0.05 and $25.8 \mathrm{~g} / \mathrm{L}$, and LOQ ranged between 0.17 and $85.9 \mathrm{mg} / \mathrm{L}$. Moreover, the recoveries of the phenolic compounds ranged from $96.9 \%$ to $106.2 \%$. The LC-MS/MS validation parameters were given in Table S1.

\subsection{Bioassays}

\subsubsection{Antioxidant activity}

To study the antioxidant activity four complementary assays; namely, $\beta$-carotene-linoleic acid system [21, 22], CUPRAC (cupric reducing antioxidant capacity) [23], DPPH free radical scavenging [24] and ABTS cation radical decolorization [25] activity assays with slight modifications [26] were used. The tests were carried out in a 96 well plate microplate reader (SpectraMax, Molecular Devices, California, USA). Results were given as $\mathrm{IC}_{50}(\mu \mathrm{g} / \mathrm{mL})$ value corresponding the $50 \%$ of the amount of the fraction and compared with BHT and a-tocopherol used as antioxidant standards. 


\subsubsection{Anticholinesterase activity}

Acetylcholinesterase (AChE) and butyrylcholinesterase (BChE) inhibitory activities were measured using a slightly modified spectrophotometric method [27, 28]. AChE from electric eel and BChE from horse serum were used. Acetylthiocholine iodide and butyrylthiocholine iodide were employed as substrates. The tests were carried out in a 96 well plate microplate reader (SpectraMax, Molecular Devices, California, USA). Results were given as $\mathrm{IC}_{50}(\mu \mathrm{g} / \mathrm{mL})$ value and compared with galantamine used as a drug in Alzheimer's patients.

\subsubsection{Determination of total phenolic concentration}

The concentration of phenolics in the fractions was performed according to the Folin-Ciocalteu method [29]. Gallic acid was used as a positive reference. Thus, the results were expressed as mg of gallic acid equivalents (GAE)/mg of dry mass.

\subsection{Statistical analyses}

All data on both antioxidant and anticholinesterase activity tests were the average of triplicate analyses. The data were recorded as mean \pm standard error meaning (S.E.M.). Significant differences between means were determined using the student's $t$-test, $p$ values $<0.05$ were regarded as significant.

Acknowledgements: The authors are grateful to DGRSDT-MESRS (Algeria), and Mugla Sıtkı Koçman University, Research Projects Coordination Office for financial support with the project number 15/116. The Sitkı Koçman Foundation (SKV) is also acknowledged by the author, M.O., and M.ED.

Author contributions: Concept - A.K., Z.K. M.O.; Design - M.O., A.E., Z.K.; Supervision - A.K., M.O., Z.K.; Resources - H.M-D., M.B.M., Z.K.; Materials - H.M-D., M.B.M., Z.K.; Data Collection and/or Processing - A.E., F.A-O., E.E.; Analysis and/or Interpretation - A.E., F.A-O., E.E.; Literature Search - H.M-D., E.E., M.B.M., M.E.D; Writing - M.O., A.K., F.A-O.; Critical Reviews - H.M-D., M.B.M., F.A-O., E.E., M.O., A.E., M.E.D., A.K., Z.K.

Conflict of interest statement: The authors declared no conflict of interest.

\section{REFERENCES}

[1] Farjon A, Rushforth KD. A classification of Abies Miller (Pinaceae). Notes from the Royal Botanic Garden, Edinburgh 1989; 46(1): 59-79.

[2] Uçar G, Uçar MB. Geographical Variation in the Composition of Abies bornmuelleriana Mattf. Needle Oils. Rec Nat Prod. 2014; 8(1): 56-60.

[3] Baydar SN. Encyclopedia of Medicinal Plants, Palme Publishing, Istanbul, Turkey 2006.

[4] Li YL, Gao YX, Jin HZ, Shan L, Chang WL, Yang XW, Zeng HW, Wang N, Steinmetz A, Zhang WD. Chemical Constituents of Abies fabri. Phytochemistry 2015; 117: 135-143. [CrossRef]

[5] Tiwari KP, Minocha PK. A Chalcone Glycoside from Abies pindrow. Phytochemistry 1980; 19(11): 2501-2503. [CrossRef]

[6] Xia JH, Zhang SD, Li YL, Wu L, Zhu ZJ, Yang XW, Zeng HW, Li HL, Wang N, Steinmetz A, Zhang WD. Sesquiterpenoids and Triterpenoids from Abies holophylla and Their Bioactivities. Phytochemistry 2012; 74: 178-184. [CrossRef]

[7] Lavoie S, Gauthier C, Legault J, Mercier S, Mshvildadze V, Pichette A. Lanostane- and Cycloartane-Type Triterpenoids from Abies balsamea Oleoresin. Beilstein J Org Chem. 2013; 9: 1333-1339. [CrossRef]

[8] Raldugin VA, Shevtsov SA. Triterpenoids of Plant of the Genus Abies Hill. Chem Nat Comp. 1990; 26: 373-382.

[9] Yang XW, Li SM, Shen YH, Zhang WD, 2008. Phytochemical and Biological Studies of Abies species. Chem Biodivers. 2008; 5(1): 56-81. [CrossRef]

[10] Benouchenne D, Bellil I, Akkal S, Bensouici C, Khelifi D. LC-MS/MS Analysis, Antioxidant and Antibacterial Activities of Algerian Fir (Abies numidica de LANNOY ex CARRIÈRE) ethyl acetate fraction extracted from needles. J King Saud Univ - Sci. 2020; 32: 3321-3327. [CrossRef]

[11] Belhadj-Mostefa M, Abedini A, Voutquenne-Nazabadioko L, Gangloff SC, Kabouche A, Kabouche Z. Abietane Diterpenes from the Cones of Abies numidica de Lannoy ex Carrière (Pinaceae) and In Vitro Evaluation of Their Antimicrobial Properties. Nat Prod Res. 2016; 31(5): 568-571. [CrossRef] 
[12] Benmerache A, Benteldjoune M, Alabdulmagid A, Abedini A, Berrehal D, Kabouche A, Gangloff SC, VoutquenneNazabadioko L, Kabouche Z. Chemical Composition, Antioxidant and Antibacterial Activities of Tamarix balansae J. Gay Aerial parts. Nat Prod Res. 2017; 31(24): 2828-2835. [CrossRef]

[13] Bouratoua A, Khalfallah A, Bensouici C, Kabouche Z, Alabdul Magid A, Harakat D, Voutquenne-Nazabadioko L, Kabouche A. Chemical Composition and Antioxidant Activity of Aerial Parts of Ferula longipes Coss. ex Bonnier \& Maury. Nat Prod Res. 2018; 32(16): 1873-1880. [CrossRef]

[14] Cherchar H, Lehbili M, Berrehal D, Morjani H, Alabdul Magid A, Voutquenne-Nazabadioko L, Kabouche A, Kabouche A. A New 2-Alkylhydroquinone Glucoside from Phagnalon saxatile (L.) Cass. Nat Prod Res. 2018; 32(9): 1010-1016. [CrossRef]

[15] Lehbili MA, AlabdulMagid A, Kabouche A, Voutquenne-Nazabadioko L, Abedini A, Morjani H, Gangloff SC, Kabouche Z. Antibacterial, Antioxidant and Cytotoxic Activities of Triterpenes and Flavonoids from the Aerial Parts of Salvia barrelieri Etl. Nat Prod Res. 2018; 32(22): 2683-2691. [CrossRef]

[16] Bensouici C, Kabouche A, Karioti A, Öztürk M, Duru ME, Bilia AR, Kabouche Z. Compounds From Sedum caeruleum with Antioxidant, Anticholinesterase, and Antibacterial Activities. Pharm Biol. 2016; 54(1): 174-179. [CrossRef]

[17] Labed-Zouad I, Ferhat M, Öztürk M, Abaza I, Nadeem S, Kabouche A, Kabouche Z. Essential Oils Composition, Anticholinesterase and Antioxidant Activities of Pistacia atlantica Desf. Rec Nat Prod. 2017; 11(4): 411-415.

[18] Jiang Y, Han W, Shen T, Wang M-H. Antioxidant Activity and Protection from DNA Damage by Water Extract From Pine (Pinus densiflora) Bark. Prev Nutr Food Sci. 2012; 17(2): 116-121. [CrossRef]

[19] Tel G, Öztürk M, Duru ME, Dogan B, Harmandar M. Fatty Acid Composition, Antioxidant, Anticholinesterase and Tyrosinase inhibitory Activities of Four Serratula Species from Anatolia. Rec Nat Prod. 2013; 7(2): 86-95.

[20] Ertas A, Boga M, Yılmaz MA, Yesil Y, Tel G, Temel H, Hasimi N, Gazioglu I, Ozturk M, Ugurlu P. A Detailed Study on the Chemical and Biological Profiles of Essential Oil and Methanol Extract of Thymus nummularius (Anzer tea): Rosmarinic Acid. Ind Crop Prod. 2015; 67: 336-345. [CrossRef]

[21] Miller HE. A Simplified Method for the Evaluation of Antioxidants. J Am Oil Chem Soc. 1971; 48: 91-105. [CrossRef]

[22] Kabouche A, Kabouche Z, Öztürk M, Kolak U, Topçu G. Antioxidant Abietane Diterpenoids from Salvia barrelieri. Food Chem. 2007; 102(4): 1281-1287. [CrossRef]

[23] Apak R, Güçlü K, Özyürek M, Karademir SE. Novel Total Antioxidant Capacity Index for Dietary Polyphenols and Vitamins C and E, Using Their Cupric Ion Reducing Capability in the Presence of Neocuproine: CUPRAC Method. J Agric Food Chem. 2004; 52(26): 7970-7981. [CrossRef]

[24] Blois MS. Antioxidant Determinations by the Use of a Stable Free Radical. Nature 1958; 181: 1199-1200.

[25] Re R, Pellegrini N, Proteggente A, Pannala A, Yang M, Rice-Evans C. Antioxidant Activity Applying an Improved ABTS Radical Cation Decolorization Assay. Free Radic Biol Med. 1989; 26(9-10): 1231-1237. [CrossRef]

[26] Demirkiran O, Sabudak T, Ozturk M, Topcu G. Antioxidant and Tyrosinase Inhibitory Activities of Flavonoids from Trifolium nigrescens subsp. petrisavi. J Agric Food Chem. 2013; 61(51): 12598-12603. [CrossRef]

[27] Ellman GL, Courtney KD, Andres V, Featherston RM. A New and Rapid Colorimetric Determination of Acetylcholinesterase Activity. Biochem Pharmacol. 1961; 7(2): 88-95. [CrossRef]

[28] Topcu G, Kolak U, Ozturk M, Boga M, Hatipoglu SD, Bahadori F, Culhaoglu B, Dirmenci T. Investigation of Anticholinesterase Activity of a Series of Salvia Extracts and the Constituents of Salvia staminea. The Nat Prod J. 2013; 3(1): 3-9.

[29] Slinkard K, Singleton VL. Total Phenol Analyses: Automation and Comparison with Manual Methods. Am J Enol Vitic. 1977; 28: 49-55. 